\title{
Offer and Acceptance in Modern Contract Law: A Needless Concept
}

\author{
Shawn J. Bayern*
}

The fundamental law of contract formation has retained the formalistic character of classical contract law. The offer-andacceptance paradigm fits poorly with modern contracting practice, and it obscures and complicates contract doctrine. More importantly, extending it threatens to produce undesirable results. Instead of the offer-and-acceptance paradigm, this Essay proposes that contract formation be analyzed using the same general interpretive inquiry that governs other questions concerning the intent of contracting parties.

Analyzing the processes of contract formation in this manner points the way toward a further-reaching reconsideration of the purposes of contract-formation law in the first place. In particular, this Essay proposes a reevaluation of the rule that parties cannot unilaterally rescind a contract immediately after the law deems it to be formed. Such a rule, too, is largely formalistic. In its place, the Essay offers a rule of contract formation that is more closely tied to the moral and instrumental purposes of contract remedies.

Introduction

I. Contract Formation: A Neglected Topic

II. The Doctrinal Distraction of "Offer and Acceptance" ............................73

A. Needless Complication

Copyright (C) 2015 California Law Review, Inc. California Law Review, Inc. (CLR) is a California nonprofit corporation. CLR and the authors are solely responsible for the content of their publications.

* Larry \& Joyce Beltz Professor, Florida State University College of Law. This Essay has benefitted from discussions with Hugh Beale, Curtis Bridgeman, Steven Burton, Melvin Eisenberg, Mark Gergen, Christopher Leslie, Hector MacQueen, Mark Seidenfeld, and Mark Spottswood. I also thank participants at the Obligations VI conference in Ontario and the Transatlantic Perspectives conference in Edinburgh for insightful, internationally comparative feedback, and those at a Berkeley Law workshop on Melvin Eisenberg's work for enlightening discussion. Not all offered criticism has been accepted. 
1. Needless Obscurity .77

2. Needless Categorization.

a. A Failure to Generalize: Implied-in-Fact Contracts and Other Similar Cases. .80

b. The Search for False Certainty.............................................. 81

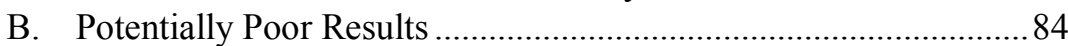

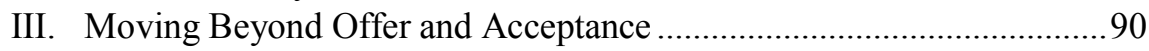

A. Conversation Plus: Putting Dialogue in Its Place ............................ 90

B. Acceptance and Irreversibility: Tying Contract Formation to the Purposes of Contract Remedies

1. Insufficient Justifications for Enforcement: Immediate Irreversibility and the Functions of Contract Enforcement......93

2. Affirmative Arguments for Reversibility ...............................98

Conclusion 100

\section{INTRODUCTION}

The notion that contracts require an offer and an acceptance is one of the last remaining bastions of classical contract law. On reflection, it is striking how poorly the offer-and-acceptance paradigm fits large areas of contracting practice; it is simply untrue that all or even most contracts are formed by means of a salient or even recognizable offer followed by a similarly salient acceptance. Instead, contracts are formed in different ways as suit the different circumstances of contracting parties. For example, the parties might contemporaneously sign a common document, shake hands, use a series of increasingly certain verbal cues to indicate that they believe themselves to be bound, or allow a third party or computer technology to match them firmly with one another. Moreover, even in cases that may fit factually into the classical offer-and-acceptance paradigm, the model tends to obscure the substantive and interpretive questions that underlie contract formation.

The problem is not necessarily debilitating. Perhaps surprisingly, doing away with the paradigm and terminology of "offer" and "acceptance" would not, on its own, amount to a radical change to modern contract law. Nonetheless, the offer-and-acceptance paradigm has a sufficiently significant effect on contract law that it is helpful to highlight its weaknesses. Most directly, exposing its problems may discourage courts and commentators from extending the model beyond the cases to which it is most directly applicable; stretching the paradigm invites at best awkwardness and at worst poor decisions. Similarly, brushing away the offer-and-acceptance paradigm can highlight useful modes of contract formation that have not received sufficient attention or study.

Perhaps more importantly, moving past the offer-and-acceptance paradigm reveals the relatively poor functional basis for what is taken to be a core principle of contract law-namely, that immediately subsequent to an 
acceptance that concludes a contract, a promise is established and expectation damages are available. This rule of irreversibility may be loosely justified on grounds of administrability, but overall it has a poor fit with both commercial practice and with the functional, substantive goals of contract law. The classical, formalistic model of contract formation should be replaced with a rule that depends more directly on the timing and possibility of performance preparations, promisee reliance, and financial speculation by one party at the expense of the other. Such a rule would comport better with morality, efficiency, and the basic underlying rationales for contract enforcement.

This Essay first, in Part I, considers the relatively scant literature on contract formation. Compared with other areas of contract law, fundamental formation doctrine has received relatively little study, and this may be why the area has progressed less beyond the classical, formalistic rules. Part II addresses doctrinal problems with the notion of offer and acceptance, essentially mounting an internal legal critique of the doctrine. The chief argument in Part II is that in view of doctrinal coherence and simplicity as well as broad congruence with contracting practice, the offer-and-acceptance doctrine should be replaced with a more direct substantive evaluation of parties' expectations. In Part III, the Essay develops a more robust theory of contract formation that takes into account both the instrumental role of damages and the noninstrumental concerns associated with enforcing promises that are retracted shortly after they are made.

I.

\section{CONTRACT FORMATION: A NEGLECTED TOPIC}

Relatively few significant articles over the last several decades have evaluated the fundamental doctrine of contract formation - the offer-andacceptance paradigm itself. Many commentators have devoted attention to a variety of important, specific formation-related problems, such as questions of precontractual liability, ${ }^{1}$ the battle of the forms, ${ }^{2}$ form contracts and related problems of assent, ${ }^{3}$ and the special problems of software contracts and other

1. See, e.g., E. Allan Farnsworth, Precontractual Liability and Preliminary Agreements: Fair Dealing and Failed Negotiations, 87 COLUM. L. REV. 217 (1987); Juliet P. Kostritsky, Bargaining with Uncertainty, Moral Hazard, and Sunk Costs: A Default Rule for Precontractual Negotiations, 44 HASTINGS L.J. 621 (1993).

2. See, e.g., Douglas G. Baird \& Robert Weisberg, Rules, Standards, and the Battle of the Forms: A Reassessment of $\$ 2-207,68$ VA. L. REV. 1217 (1982); Victor P. Goldberg, The "Battle of the Forms": Fairness, Efficiency, and the Best-Shot Rule, 76 OR. L. REV. 155 (1997); Daniel Keating, Exploring the Battle of the Forms in Action, 98 MicH. L. REV. 2678 (2000); John E. Murray, Jr., The Chaos of the "Battle of the Forms": Solutions, 39 VAND. L. REV. 1307 (1986).

3. See, e.g., Shmuel I. Becher, Behavioral Science and Consumer Standard Form Contracts, 68 LA. L. REV. 117 (2007); David Gilo \& Ariel Porat, The Hidden Roles of Boilerplate and StandardForm Contracts: Strategic Imposition of Transaction Costs, Segmentation of Consumers, and Anticompetitive Effects, 104 MiCH. L. REV. 983 (2006); Robert A. Hillman, Rolling Contracts, 71 FORDHAM L. REV. 743 (2002); Russell Korobkin, Bounded Rationality, Standard Form Contracts, and 
online contracts. ${ }^{4}$ My concern is more fundamental than these particular problems - it is with the foundational doctrine of offer and acceptance itself. ${ }^{5}$

In the last twenty years or so, there have been some interesting contributions to foundational contract-formation doctrine from legal-economic scholars. In 1990, Avery Katz analyzed contract formation in terms of game theory. ${ }^{6}$ His analysis was largely descriptive and informative, showing the effects of various bargaining rules on the decisions of rational (and imperfectly rational) parties. ${ }^{7}$ For example, Professor Katz identified several sorts of transaction costs that legal rules governing bargaining might create, including costs of communication and, probably more notably, costs of "strategic behavior." " Thus, for example, parties might bluff, adopt hard lines in bargaining, and do other things that have the potential to destroy or enhance value. As a whole, Katz sought to provide clearer ways to consider formation doctrine and to understand its incentive effects.

Unconscionability, 70 U. CHI. L. REV. 1203 (2003); John E. Murray, Jr., The Dubious Status of the Rolling Contract Formation Theory, 50 DUQ. L. REV. 35 (2012).

4. See, e.g., Juliet M. Moringiello, Signals, Assent and Internet Contracting, 57 RUTGERS L. REV. 1307 (2005); David A. Szwak, Uniform Computer Information Transactions Act [U.C.I.T.A.]: The Consumer's Perspective, 63 LA. L. REV. 27 (2002).

5. Even Grant Gilmore's wide-ranging book criticizing classical contract law does not offer a specific critique of foundational offer-and-acceptance doctrine. See generally GRANT GILMORE, THE DEATH OF CONTRACT (Ronald K.L. Collins ed., 2d ed. 1995).

Ian R. Macneil and Stewart Macaulay's relational view of contracting addresses broader concerns but does recognize the potential "fuzziness" of formal acceptance that I discuss in Parts II and III. For example, Macneil has written:

The context of "I accept employment on your terms" is a recognition of the inevitable tentativeness of consent to a relation, the inevitable mutuality of future superseding events, and all the rest of the elements which, in a relation, cause even the clearest expression of adhesive consent to suffer from essential fuzziness.

Ian R. Macneil, The Many Futures of Contracts, 47 S. CAL. L. REV. 691, 771 (1974); see also Stewart Macaulay, Non-Contractual Relations in Business: A Preliminary Study, 28 AM. Soc. Rev. 55, 55 (suggesting that businesspeople often do not "plan exchange relationships completely"). Though my approach to contract law is sympathetic with many features of the relational theorists' arguments, the principles I develop do not generally turn directly on the status of a prior relationship. My inquiry is, in some sense, broader and more fundamental, and it aims to analyze contract doctrine directly and generally. Cf. Melvin A. Eisenberg, Why There Is No Law of Relational Contracts, 94 Nw. U. L. REV. 805, 821 (2000) (praising relational contract theory in several respects but noting that it has not developed a "law of relational contracts" because there is "no significant difference between contracts as a class and relational contracts" and, accordingly, "relational contracts must be governed by the general principles of contract law, whatever those should be.").

6. See Avery Katz, The Strategic Structure of Offer and Acceptance: Game Theory and the Law of Contract Formation, 89 MiCH. L. REV. 215 (1990).

7. Katz agrees with me about the relative paucity of analytical study of offer-and-acceptance rules, at least as of 1990 and with regard to economic commentary:

[T] he mechanical rules of contract formation so beloved to hornbook authors and bar examiners, and the related body of legal doctrine that helps imply the content of the contract from the history of the bargaining, largely have escaped attention from those legal scholars influenced by economics. The preponderance of the literature treats such rules as largely conventional, and accordingly irrelevant for purposes of policy analysis.

Id. at 218 (footnote omitted)

8. See id. at 226. 
In an interesting and helpful article a few years later, Richard Craswell analyzed contract formation and related it to the notion of efficient reliance in light of possible breach. ${ }^{9}$ To understand Craswell's article, it is important to understand the (hotly contested) economic notion that contract law should recognize that promisees cannot always expect performance and thus should not always rely on promises. ${ }^{10}$ Consider the following example:

Yvonne owns a restaurant for economists called the Waffle Shop. Business is going well, and Yvonne contracts with Xavier to build a new facility to be ready for occupancy by September 1 . Many things could prevent Xavier from completing on time-bad weather, a plumbers' strike, overscrupulous or unscrupulous city inspectors, and so on. To serve the new customers who will patronize the new facility, Yvonne must order more food, and she must order it before September 1. Greater expenditures on food will increase her profits from the restaurant, since she will then be able to serve more customers in the period following September 1.

Under the standard calculation of expectation damages, a promisee will increase expenditures in reliance on a contract up to the point where the expected gain from an incremental increase in such expenditures equals the cost of the incremental increase. Now, even if the promisor fully internalizes all the costs of breach that are borne by the promisee, there is some chance that the promisor (Xavier, in the hypothetical) will breach-for example, if the costs of performing unexpectedly turn out to be prohibitive. In choosing the socially optimal amount of reliance on the contract, the promisee (Yvonne, in the hypothetical) should take this chance of non-performance into account. However, the standard expectation measure does not give the promisee an incentive to choose the socially optimal level of reliance. In particular, when calculating the expected gain from an increase in reliance expenditures, the promisee will not discount that expected gain by the probability that the promisor will breach. From the promisee's point of view, it is as if the promisor had insured the promisee that the contract would be performed. The promisee thus acts as if performance is certain, and chooses a level of reliance on the promise consistent with that assumption. The level of reliance so chosen will be higher than the level that would be chosen if the

9. See Richard Craswell, Offer, Acceptance, and Efficient Reliance, 48 STAN. L. REV. 481 (1996).

10. See Steven Shavell, Damage Measures for Breach of Contract, 11 BELL J. ECON. 466 (1980) (modeling the relationship between remedial regimes and overreliance); Steven Shavell, The Design of Contracts and Remedies for Breach, 99 Q.J. ECON. 121, 124 (1984); but see Shawn J. Bayern \& Melvin A. Eisenberg, The Expectation Measure and Its Discontents, 2013 MicH. ST. L. REV. 1, 6-13 (2013); Melvin A. Eisenberg \& Brett H. McDonnell, Expectation Damages and the Theory of Overreliance, 54 HASTINGS L.J. 1335, 1373-74 (2003) (critiquing the notion that overreliance should affect contract law and concluding instead that "[w] hen institutional considerations are taken into account ... the theory has virtually no consequences."). 
promisee assumed that the promisor had a positive probability of breach. Choosing the higher level is inefficient. Accordingly, the expectation measure is flawed. ${ }^{11}$

In view of this potential drawback of expectation damages, Professor Craswell's article on the offer-and-acceptance paradigm argued that it is at least possible that rules of contract formation can promote efficient reliance. In particular, he concluded descriptively that courts tend to find that enforceable contracts have been formed (via rules of offer and acceptance) when they judge that the promisee's reliance would have been efficient. ${ }^{12}$ Normatively, however, he concluded that it would be difficult to fashion specific rules of contract formation to encourage efficient reliance on promises, largely because efficient reliance needs to be determined case by case. ${ }^{13}$

For my purposes, the most helpful modern article on contract formation is by leading contract-law scholar Melvin Eisenberg. In 1994, Professor Eisenberg introduced the notion of expression rules as a way to analyze, doctrinally and normatively, contract law's rules of contract formation. ${ }^{14}$ The fundamental insight of Professor Eisenberg's article is that many specific rules of offer and acceptance are really just crude substitutes for the general rules of contract interpretation - that is, bright-line rules about how to interpret certain types of expressions that parties make to one another.

For example, contract law has a rule that ordinary advertisements do not constitute offers. ${ }^{15}$ If there were no such rule, then in evaluating whether a particular advertisement is an offer for the purposes of contract law, we would simply ask whether a reasonable person reading it would interpret it as an offer. Essentially, we would apply ordinary interpretive rules to determine the legal effects of an advertisement, just as we do to analyze most other potential offers. Indeed, Eisenberg provides a persuasive account that most people would, under most circumstances and contrary to the technical rule of contract law, believe that advertisements are offers. ${ }^{16}$ It is not clear, as a result, why the historical rule about advertisements is desirable. ${ }^{17}$ At the very least, if the rule is justifiable, it is probably justifiable despite contracting parties' expectations, not because of them.

As another example, Eisenberg considers the rule that an offer made during a conversation (in person or over a telephone call) lapses at the end of

11. Melvin A. Eisenberg \& Brett H. McDonnell, Expectation Damages and the Theory of Overreliance, 54 HASTINGS L.J. 1335, 1337-38 (2003) (paraphrasing and analyzing ROBERT COOTER $\&$ THOMAS UlEN, LAW AND ECONOMICS 248-57 (3d ed. 2000)).

12. Craswell, supra note 9, at 508-31.

13. Id. at $544-53$.

14. Melvin Aron Eisenberg, Expression Rules in Contract Law and Problems of Offer and Acceptance, 82 CALIF. L. REV. 1127 (1994).

15. Id. at 1166-72.

16. See id.

17. Id. at 1171-72. 
the conversation. ${ }^{18}$ Parties might or might not expect the operation of this rule, but the rule is again easier to justify - in terms of the morality and efficiency associated with promises - if they do. If not, the rule potentially undermines both the opportunity for efficient deals and the morality of promises. ${ }^{19}$ That is, if parties expect a deal that is cut off by the bright-line rule that offers lapse at the end of conversations, then the law refuses to recognize a deal that they wanted and under which at least one of them has promissory obligations.

Eisenberg's general thesis is that, with few exceptions, most of the expression rules in contract-formation doctrine are unjustified and that the law should move (and is moving) away from such rules and toward general principles of interpretation: "For the most part, therefore, expression rules that are justified at all should be cast as either weak presumptions or as maxims. If we look past the black-letter rules to the case law, that is just the direction in which contract law is moving." ${ }^{20}$ As we will see in Part III, a central thesis of this Essay is essentially to expand Eisenberg's argument in the following way: general interpretive principles should replace not just individual expression rules (operating within the offer-and-acceptance paradigm) but the whole notion of offer and acceptance. Just as individual rules governing whether advertisements are offers may be judged by how well they vindicate the expectations of commercial parties, applying the same analysis to the offerand-acceptance doctrine shows that it does no better, in practice or in theory, than a general interpretive inquiry - that is, the ordinary legal construction of the parties' intent.

II.

THE DOCTRINAL DISTRACTION OF “OFFER AND ACCEPTANCE"

This Part contends that the threshold question of contract formation that is addressed by the doctrine of offer and acceptance should be replaced by a simpler, more straightforward inquiry: Does one of the parties to a potential contract reasonably believe there is a contract? This is the preliminary result achieved when the offer-and-acceptance doctrine works properly, and indeed it is the ordinary result. For example, if Buyer makes an offer to Seller to purchase a parcel of real property for $\$ 250,000$ and Seller responds in a potentially ambiguous manner, contract law will ordinarily evaluate Seller's use of language from the perspective of a reasonable person in Buyer's position; it will ask, in other words, whether Buyer reasonably believes that Seller accepted Buyer's offer. ${ }^{21}$ That is fundamentally the same general question I am proposing.

18. See id. at $1153-56$.

19. See id.

20. Id. at 1180 .

21. See Restatement (SeCOND) OF CONTRACts § 57 (1981) ("Where notification is essential to acceptance by promise, the offeror is not bound by an acceptance in equivocal terms unless 
Distinguishing between subjective and reasonable objective belief may be useful here, although the interplay between subjectivity and objectivity in contract law is complicated. Where both parties subjectively believe there is a contract, that shared belief is ordinarily sufficient, at least under modern American contract law, for there to be a contract. ${ }^{22}$ Where neither party believes there is a contract, the prominence of subjective intent is similar: there is no contract. ${ }^{23}$ The difference between the "subjective" interpretations that the parties actually hold and the "objectively reasonable" interpretations that those in the parties' positions might hold arises only when the parties' subjective understandings are different. In that case, the more reasonable meaning prevails (except where one of the parties knew or should have known of the misunderstanding). ${ }^{24}$

To clarify this Part's thesis in view of the distinctive roles of subjectivity and objectivity in modern American contract law, then, it is that the following principles should replace the offer-and-acceptance doctrine: (1) if both parties believe there is a contract, there should be a contract; (2) if one of the parties believes there is a contract, and that belief is more reasonable than the other party's belief that there is no contract, there should be a contract. (This is just an elaboration of the simpler principle I stated at the outset. $)^{25}$

he reasonably understands it as an acceptance."); $c f . i d$. $\S 24$ ("An offer is the manifestation of willingness to enter into a bargain, so made as to justify another person in understanding that his assent to that bargain is invited and will conclude it.").

22. See id. § 201(1) ("Where the parties have attached the same meaning to a promise or agreement or a term thereof, it is interpreted in accordance with that meaning."); Eisenberg, supra note 14, at 1134 ("Restatement Second stands the classical school's position on its head by giving primacy to mutually held subjective interpretation, and resorting to an objective or reasonable meaning only in the absence of a mut[u]ally held subjective meaning.").

23. See Restatement (SECOND) OF CONTRACTS § 201(1) (1981); 6 Peter LinZer, Corbin ON CONTRACTS $\S 25.1$ (Joseph M. Perillo ed., 2010) ("No contract should ever be interpreted and enforced with a meaning that neither party gave it.").

24. See RESTATEMENT (SECOND) OF CONTRACTS § 201(2) (1981) ("[T] by [the first party prevails when] (a) that party did not know of any different meaning attached by the other, and the other knew the meaning attached by the first party; or (b) that party had no reason to know of any different meaning attached by the other, and the other had reason to know the meaning attached by the first party."). Note that the Restatement technically appears to draw a dichotomy between reasonable and unreasonable interpretive beliefs, rather than to conceive reasonableness on a spectrum and to favor the better of two potentially reasonable interpretations. Cf. Melvin Aron Eisenberg, The Role of Fault in Contract Law: Unconscionability, Unexpected Circumstances, Interpretation, Mistake, and Nonperformance, 107 MICH. L. REV. 1413, 1422-24 (2009) (generalizing from the Restatement in a similar way to find an interpretive principle based on the parties' fault).

25. Another elaboration may be worthwhile. To say that the test should be whether at least one of the parties thinks there is a contract (or both subjectively do) is potentially vague; it may help to add that the reasonable belief (or shared subjective belief) is about particular enforceable contract terms. In my view, the appropriate question for courts to ask is almost never "Is there a contract?" but rather "What enforceable terms, if any, are there between the parties?"

Accordingly, the beliefs of the contracting parties that I have in mind in the text are those concerning the existence of (usually specifiable) enforceable terms, not merely the existence vel non of a contract in the abstract. As it turns out, almost nothing in contract law depends on the precise establishment or timing of the formation of "a contract" rather than of particular duties under it; though 
Instead of applying these general principles of interpretation, the current fundamental law of "offer and acceptance" (and again, by fundamental I refer to the core presence of the doctrine, not to the many ancillary rules about when and whether an offer can be revoked, precisely when various communications are legally effective, precontractual liability, and so forth) serves as a workable but potentially awkward placeholder. The existing fundamental rules present two closely related dangers discussed below: (A) needless complication and (B) potentially poor results as the basic offer-and-acceptance paradigm is stretched.

\section{A. Needless Complication}

The simple mismatch between courts' descriptions of the doctrine and frequent contracting practice demonstrates the needless complication of the current doctrine. Courts often declare that contracts require offer and acceptance, ${ }^{26}$ but contracting practice itself suggests otherwise, or at least suggests that the definitions of offer and acceptance are often very thinly stretched.

For example, a common way to conclude a contract is for two parties to sign a document together. If the signatures are literally simultaneous (or their processes overlap temporally), there is no sequence of final communications; there is simply a joint act creating a contract. The same applies to shaking hands, which is perhaps an even more conventional way of indicating an agreement. In these cases, there is no discrete, identifiable sequence of offer and acceptance.

Even in the case where one party signs a contract just before another (so that there is technically a sequence of events leading up to contract formation), to call the first signature an offer and the second an acceptance may be distracting and even untenable. If nothing else, such terminology stretches the ordinary definitions of the terms and seems to serve little function. Perhaps in

that matter is beyond the scope of this Essay, it is worth pointing out that even largely formal endeavors, like computations of the intervals associated with statutes of limitations, depend on the timing of breach (of particular duties) rather than of formation.

26. See, e.g., Int'l Bus. Machs. Corp. v. Johnson, 629 F. Supp. 2d 321, 330 (S.D.N.Y. 2009) ("The formation of a valid, express contract under New York law requires an offer, acceptance, consideration, mutual assent, and intent to be bound."); Dantz v. Apple Ohio LLC, 277 F. Supp. 2d 794, 801 (N.D. Ohio 2003) ("What is required to validate the arbitration agreement and make it contractual is an offer and acceptance, supported by consideration."); In re Estate of Kampen, 135 Cal. Rptr. 3d 410, 425 (Ct. App. 2011) ("It is elementary that a contract requires an offer and acceptance....."); R.C. Constr. Co. v. Nat'l Office Sys., 622 So. 2d 1253, 1255 (Miss. 1993) (“It is basic contract law that a contract requires an offer and acceptance."); May v. Anderson, 119 P.3d 1254, 1257 (Nev. 2005) ("Basic contract principles require, for an enforceable contract, an offer and acceptance, meeting of the minds, and consideration"); Cargill, Inc. v. Kavanaugh, 228 N.W.2d 133, 138 (N.D. 1975) ("Basically, Hornbook law (i.e., Simpson on Contracts) tells us that a contract requires an offer, and acceptance of that offer, and mutual acceptance and understanding of the offeror and offeree as to the terms of the legally enforceable obligation thus incurred."). 
some cases the act of signing a document is meant to convey an offer ("I have committed; now it is your turn to do so"), but this is not necessarily true. In the typical case of jointly signed agreements, the parties have worked out the details through an ongoing process in which they gradually reached an understanding, in no particular sequence, and understand that they will finalize the deal by signing a document jointly. That is, the second-to-last step in forming a contract might not have any role in inviting the final one. And, to say that the offer-and-acceptance paradigm is serviceable because courts and commentators can always identify some second-to-last act (called an offer) and some final act (called an acceptance) that bring a contract into existence ${ }^{27}$ seems to miss the point that many such acts are not offers or acceptances except in a very stylized sense. More subtly (and admittedly fancifully), when contracts are concluded at a distance, it may be not only practically impossible to say which act was the second-to-last and which was the last, but also theoretically indeterminate under the theory of special relativity. ${ }^{28}$

More practically speaking, contract doctrine at best spins its wheels needlessly in trying to classify various actions as offers or acceptances when it should be asking a more direct interpretive question concerning the parties' intent. This problem manifests itself in two ways: (1) the doctrine obscures the underlying substantive questions of modern contract law, and (2) it adopts needless categories that, as I have already suggested, fit poorly with practical contracting practice.

27. See, e.g., Jay M. Feinman \& Stephen R. Brill, Is an Advertisement an Offer? Why It Is, and Why It Matters, 58 HASTINGS L.J. 61, 64 (2006) (referring in passing to a classical theory of contract law that equates an offer with "the penultimate step in the creation of a legal relationship").

28. The theory of special relativity teaches us, counterintuitively, that simultaneity in the absence of causation is relative; that is, determining the sequence of events depends on an arbitrary selection among many possible reference points. If two events $(A$ and $B)$ occur in different places and are not causally related, it is consistent with the universe to say, from various perspectives, that $A$ occurred first, that $B$ occurred first, or that $A$ and $B$ were simultaneous. See ALBERT EINSTEIN, Relativity: The Special And General Theory (1920); D. F. Comstock, The Principle of Relativity, 31 SCI. 767, 769 (1910) ("Neither the standpoint of the 'moving' observer nor our standpoint is wrong. The two merely represent two different sides of reality."). So when an offer does not in fact invite the particular acceptance at issue (and thus serve as what business people typically mean by "offer"), it may be theoretically impossible to say in an absolute or objective sense which of the parties' acts, concluded at some distance from one another, occurred first. I don't suppose this theoretical limitation is particularly important from a practical perspective when contracts are concluded on Earth or its vicinity (any more than, for example, I think that Gödel's incompleteness theorem poses practical challenges for interpreting contracts, though some may think that). See generally Mike Townsend, Implications of Foundational Crises in Mathematics: A Case Study in Interdisciplinary Legal Research, 71 WASH. L. REV. 51 (1996) (discussing generally the overreaching of mathematical theory, including Gödel's theorem, in areas beyond its domain). But it is at least interesting that a conceptualist model of contract law that wishes to declare every contract formed through a sequence of events, of which one is an offer and one is an acceptance, can theoretically run into a physical boundary that makes it impossible to say which is which. In other words, while physical theory probably does not matter directly in setting general rules for how contracts are formed, it may still be worthwhile to recognize that the conceptual simplicity sought by classical contract law may not even be consistent, in all cases, with the real universe. 


\section{Needless Obscurity}

As an example of the first problem, consider International Filter Co. v. Conroe Gin, Ice \& Light Co. ${ }^{29}$ International Filter, which made water filters, sent its representative (the appropriately named Mr. Waterman) to negotiate with buyers. Mr. Waterman sent a document to a potential buyer that read as follows:

Gentlemen: We propose to furnish, f.o.b. Chicago, one No. two Junior (steel tank) International water softener and filter to purify water of the character shown by sample to be submitted. $* * *$

Price: Twelve hundred thirty $(\$ 1,230.00)$ dollars. $* * *$

This proposal is made in duplicate and becomes a contract when accepted by the purchaser and approved by an executive officer of the International Filter Company, at its office in Chicago. Any modification can only be made by duly approved supplementary agreement signed by both parties.

This proposal is submitted for prompt acceptance, and unless so accepted is subject to change without notice.

Respectfully submitted,

International Filter Co.,

W.W. Waterman. ${ }^{30}$

This document elicited a response, in the form of a letter, by the buyer:

Accepted Feb. 10, 1920. Conroe Gin, Ice, and Light Co.,

By Henry Thompson, Mgr. ${ }^{31}$

Subsequently, at the Chicago office of International Filter, an officer described as "its President and Vice-President" wrote on the letter "O.K." with the date and his name, and thereafter International Filter wrote a letter to the buyer confirming the order. ${ }^{32}$ The buyer later sought to cancel the order against International Filter's wishes, and thus a contract dispute arose. ${ }^{33}$ In particular, the buyer alleged that no contract had been formed, in part because the internal notation of an acceptance by an officer of International Filter was not legally an acceptance. $^{34}$

The court held that under traditional contract-law principles, the original document signed by Waterman was not an offer because the buyer could not accept it; it was just what is sometimes called an "invitation to deal." 35 The response by the buyer indicating that the buyer had "[a]ccepted" the terms of a

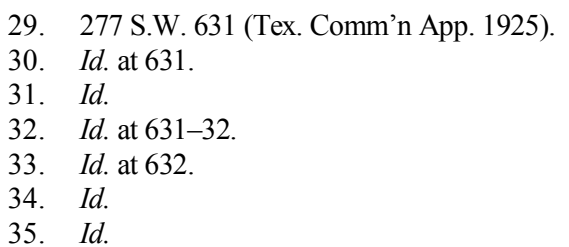


deal was correspondingly just itself an offer, and the acceptance and thus formation of a contract occurred when International Filter's officer wrote "O.K." on the document. ${ }^{36}$

The court's determination that there was a binding contract seems correct, at least on the facts it reported; that is, International Filter appears reasonable in believing that a contract had been formed. ${ }^{37}$ But the court's treatment of the various documents seems, at best, roundabout. The original document issued by Waterman had all the substance of an offer except that it required a final step for approval, signaling that Waterman was not himself authorized to conclude a contract. The buyer clearly perceived the self-styled acceptance as an acceptance, not an offer. It may have been an acceptance of a conditional offer (conditioned on further approval), but it was still substantively an expression of a definite intent to be bound to terms that had already been proposed.

Instead of treating the writing of "O.K." by International Filter's officer as the act that formed a contract, the requirement for later approval should be analyzed simply as a condition for performance. This form of analysis has several advantages over the court's. First, it's simpler: it doesn't require introducing a new kind of acceptance (which at least one leading American contract-law casebook calls "subjective acceptance"). ${ }^{38}$ Second, it accords more readily with the bilateral nature of the contract in International Filter. The response by Conroe Gin is arguably not a promise, and if the original document from Waterman is interpreted as an invitation to deal, it arguably contains no enforceable promise either. Yet it is clear that both parties have ongoing obligations once a contract is formed.

Third, the more general "condition" analysis seems to accommodate a wider range of cases. For instance, I assume there would be a contract (with a condition) if International Filter's original document demanded later "approval" by a state regulatory agency or another interested third party instead of from International Filter itself. In that case, the original document and the response would be sufficient to give rise to a contract. Under the subjective acceptance analysis, this sufficiency can evaporate based only on the identity of the party whose later approval is required. There's nothing inherently wrong with that result if it doesn't change the parties' rights and duties, but it is doctrinally cumbersome; the forms of the proposal and acceptance haven't changed, but their nature and effects differ depending on whose later approval is required.

Perhaps more significantly, what if International Filter's original document (which otherwise had the characteristics of an offer) had contained the following provision: "Neither party will have any obligations unless

\footnotetext{
36. $I d$.

37. Id. at 632-33.

38. LON L. FUlLER ET AL., BASIC CONTRACt LAW 530-34 (9th ed. 2013).
} 
executives from both our organizations - separately and subjectively - approve this transaction"? Suppose the buyer then "accepted" this proposal, and the parties each then forwarded the agreement to their executives, who both approved it. If contractual liability results, as it should because the parties both intend to be bound, ${ }^{39}$ the "condition" analysis would lead us to say simply that International Filter's proposal is an offer and the buyer's agreement an acceptance - that is, an offer and an acceptance of a contract with two distinct conditions. By contrast, under the "subjective acceptance" analysis that the International Filter court used, it seems as if the subjective executive approval that happens to occur first is something like a "subjective offer" and the second a "subjective acceptance." There is little problem in saying this if it is the only way to reach the right result under existing doctrine, but it is cumbersome and entirely unnecessary.

I strongly suspect that the only reason that the International Filter court introduced the notion of "subjective acceptance" was classical contract law's refusal to see consideration in an "illusory" promise. Under classical contract principles, if International Filter can later choose not to be bound, there must (by deduction) be no contract. ${ }^{40}$ But under modern contract law's significantly less formal views of consideration, it is easy to see the mutual consideration in the various hypothetical contracts I have outlined. Once we brush away the illusory-promise doctrine, a more general principle for contract formation emerges that is both simpler and more expressive than the offer-and-acceptance doctrine: specifically, there is no essential difference between (on one hand) a contract with performance conditioned on an event and (on the other hand) a commercial promise conditioned on the offeree's acceptance. Acceptance is just one kind of event on which a promise's performance can be conditioned. If, as leading functionalist scholars have proposed, questions of consideration in contract law exist largely to differentiate commercial from noncommercial promises ${ }^{41}$ there is likely no consideration-based reason to distinguish an

39. Alternatively, if there is no contract, it is hard to see why. That is, why should an extra step (such as prior explicit approval by one executive) be necessary for two agents to conditionally bind one another's principals based on those principals' subsequent internal acts if the agents so agree and the principals so approve?

40. See 1 Samuel Williston, A Treatise on the LaW of Contracts $\S 103 \mathrm{~B}$ (rev. ed. 1936) (stating the classical illusory-promise rule).

41. See, e.g., 2 ARTHUR L. CORBIn, CORBIN On CONTRACTS $\S 5.17$ (Joseph M. Perillo ed., rev. ed. 1995) ("Consideration is designed primarily to protect promisors from their own donative promises."); Melvin Aron Eisenberg, The World of Contract and the World of Gift, 85 CALIF. L. REV. 821 (1997). To put this perhaps more precisely, the wisdom of "consideration" may lie only in its separation of affective from commercial contexts; beyond that, there is little need to draw rigid distinctions that rule out commercial expectations from governing. Accordingly, an offer to do an act conditional on acceptance is really just a unilateral promise to do something that commercial norms dictate ought to be done on acceptance, given trade customs and the facts of particular circumstances. Perhaps the acceptance makes the promise enforceable only because the promise was conditioned on whatever acts constituted acceptance, not because the acceptance adds anything relevant (as "consideration") to distinguish the case as a commercial rather than an affective one. 
acceptance from any other kind of event on which a promise's performance may be conditioned. "I promise to paint your house if you'll agree to pay me $\$ 400$ " should receive the same treatment as Mr. Waterman's original document; there is no substantively relevant difference between the two cases.

Indeed, sensitive courts have analyzed contract formation in a way broadly consistent with what I am suggesting. In Jaybe Construction Co. v. Beco, Inc., ${ }^{42}$ for example, the court recognized that a deal that had otherwise been offered and accepted might be conditioned on a further step, such as reducing an agreement to writing (presumably, at some later time that could be identical for both parties). ${ }^{43}$ Similarly, Atlantic Terra Cotta Co. v. Chesapeake Terra Cotta Co. recognized the possibility that "acceptance [] of an offer" could be "conditional on the execution of a formal contract" by the parties. ${ }^{44}$ There is little functional reason to avoid such possibilities.

\section{Needless Categorization}

The prior Section shows ways in which the offer-and-acceptance paradigm complicates individual cases by obscuring the reasoning process that is needed to reach functional results. This Section generalizes somewhat in order to show ways in which the offer-and-acceptance paradigm also complicates the structure and categorization of contract-law doctrine.

\section{a. A Failure to Generalize: Implied-in-Fact Contracts and Other Similar Cases}

For one thing, the offer-and-acceptance paradigm has led to an unnecessary fragmentation of doctrines concerning formation. As discussed earlier, many real world contracts are created without any explicit "acceptance" or "offer-and-acceptance" pattern. For example, if I pass by a newsstand at which I am a regular customer and familiar with the proprietor, and in a rush I take a newspaper and nod toward the proprietor, pointing at my watch, the proprietor and I likely have a contract for the sale of goods on the usual terms by which we buy and sell daily newspapers. ${ }^{45}$ Modern contract law recognizes an obligation here, but it does so by treating the interaction as a contract "implied in fact." Implied-in-fact contracts have the same legal effects as express contracts, but they arise differently and do not require an offer or an acceptance, except perhaps a fictional one. It is unnecessary to create a separate doctrinal category for these cases instead of recognizing that there is a contract (like any other contract) simply because the parties would reasonably believe

42. 216 A.2d 208 (Conn. Cir. Ct. 1965).

43. See id. at 211-12.

44. 113 A. 156, 158 (Conn. 1921).

45. This example is a generalization of RESTATEMENT (SECOND) OF CONTRACTS $\S 4 \mathrm{cmt}$. a, illus. 2 (1981) (“A, on passing a market, where he has an account, sees a box of apples marked '25 cts. each.' A picks up an apple, holds it up so that a clerk of the establishment sees the act. The clerk nods, and A passes on. A has promised to pay twenty-five cents for the apple."). 
under the circumstances that they are obliged to each other on familiar terms. To put it differently, while International Filter highlights an area where the offer-and-acceptance doctrine causes the analysis of a class of cases to be more complicated, the separation of "implied in fact" from ordinary contracts shows a more general problem of doctrinal complication through unnecessary classification.

The law of implied-in-fact contracts is not the only doctrine that the offerand-acceptance model complicates. As I suggested earlier, any case where there is a simultaneous, in-person expression of an agreement $-\mathrm{a}$ joint signed statement, an agreement to form many kinds of companies (such as a partnership or an LLC), and so on-might exhibit no offer-and-acceptance pattern. The law seems to respond to these factual patterns by simply ignoring their differences from the standard offer-and-acceptance model. Because questions of offer and acceptance rarely arise in these cases, courts have likely had little reason to consider the question carefully. But courts do of course acknowledge that assent can be concurrent rather than sequential, and can involve two parties or more than two parties (in which case the offer-andacceptance model becomes cumbersome very quickly). ${ }^{46}$ The case of businessorganization agreements is interesting for a related reason: they often, by their presence, give rise to a broader change in legal status among the parties. It is fine to say that such changes have nothing to do with the essence of "contract law," but that sort of essentialism creates legal categories that are justified only by circular reasoning. In other words, it seems better to say simply that by agreeing to co-own a business, parties agree to other rights and duties as a result of their circumstances. This agreement is not fictional, but it may not come from anything related to classical "offer" or classical "acceptance." It comes from the reasonable expectations of the parties.

\section{b. The Search for False Certainty}

The offer-and-acceptance paradigm also neglects alternative modes of contract formation, often in the name of legal certainty. It is not even clear, however, that the typical case of contract formation in fact involves an offer followed by an acceptance. Communications called "offers" are not rare, but often what they offer is a price, or some other term - not a contract. The contract comes into being only through a series of increasingly certain cues, or from the development of business circumstances, such as in cases where courts hold that a contract exists because of "acceptance by conduct.",47

46. See, e.g., Virginia v. West Virginia, 78 U.S. 39, 63 (1871) (Davis, J., dissenting) (discussing a multiparty interstate compact and referring to "a reciprocal and concurrent consent of the three parties to the contract").

47. See, e.g., Polaroid Corp. v. Rollins Envtl. Serv. (NJ), Inc., 624 N.E.2d 959 (Mass. 1993). And, of course, promissory estoppel in general follows no offer-and-acceptance pattern. 
On reflection, several salient alternatives to the classical offer-andacceptance paradigm emerge. In one type of case, we are confident an agreement arises from a muddle of events, but we cannot say how-nor is it necessarily important to do so. ${ }^{48}$ For an extreme example of this, consider comedian Alun Cochrane's assertion that his marriage proposal was never explicit and simply matured naturally during ordinary conversation: "I never had a proposal. Our marriage is honestly a conversation that got out of hand.... We were just having a chat; my wife was washing up, and then we were booking a wedding." ${ }^{49}$ As a matter of casual empiricism, this pattern is not unusual or problematic (except, of course, for marriage proposals!). Parties often do not have the rules of contract law specifically in mind in their interactions; those interactions proceed informally, reaching at some point a threshold past which it is clear to the parties (if they are reasonable) that they are bound. Parties will never have absolute certainty that they have reached an agreement; what they need is reasonable confidence. The distinction between absolute certainty and reasonable confidence (and between legal certainty and practical certainty) is not appreciated enough; legal rhetoric often emphasizes the former, forgetting that it is unattainable and that moving toward it is not desirable in all contexts. ${ }^{50}$

The opinion in Adams v. Lindsell, ${ }^{51}$ famous for originating the "mailbox rule" in contract law, ${ }^{52}$ presciently anticipated a problem in seeking certainty in contract formation. That problem was later formalized in the informational theory underlying modern computer networking. The court in Adams adopted the mailbox rule essentially to accelerate contract formation, admitting that such a rule might lead to some uncertainty for parties but recognizing that absolute certainty in reaching an agreement is impossible to achieve using an unreliable communicative technology:

[T] he Court said, that if [we required each party to be confident that the other party had received its communication before finding an enforceable contract], no contract could ever be completed by the post. For if the defendants were not bound by their offer when accepted by the plaintiffs till the answer was received, then the plaintiffs ought not to be bound till after they had received the notification that the

48. This is roughly a contractual analogue to the notion of res ipsa loquitur in tort law: we may know there is a contract but be unable to say precisely how it arose, just as in res ipsa cases, we may know there was negligence but may be unable to specify precisely what it was. See RESTATEMENT (SECOND) OF TORTS § 328D (1965) (summarizing the tort doctrine of res ipsa loquitur).

49. Frank Skinner's Opinionated (BBC television broadcast Nov. 17, 2011).

50. See Shawn J. Bayern, Against Certainty, 41 Hofstra L. ReV. 53 (2012).

51. (1818) 106 Eng. Rep. 250 (K.B.).

52. See Restatement (SECOND) OF COntracts $\S$ 63(a) (1981) (“[A]n acceptance... completes the manifestation of mutual assent as soon as put out of the offeree's possession. ..."); id. at $§ 63 \mathrm{cmt}$. a (calling this the "mailbox rule"). 
defendants had received their answer and assented to it. And so it might go on ad infinitum. ${ }^{53}$

A century and a half later, this intuition was proven as a matter of epistemic logic (the logic of knowledge and belief) and computer networking theory. ${ }^{54}$ Mathematicians and network theorists know this pattern of communicative fragility as the "Two Generals Problem." "In the scenario usually discussed, ${ }^{56}$ two allied generals are located at a distance from each other and can communicate about their readiness for an attack only over an unreliable medium, like carrier pigeons that might be shot down or otherwise fail to reach their destination. Their military strategy requires them to attack a common enemy either together or not at all. The question is whether, under these conditions, they can ever mount an attack. If absolute certainty in agreement is required, the answer-as the Adams court saw-is that they cannot. The first general cannot attack until she sends the second general a message and confirms that it has been received; the second general cannot attack until he receives the message, writes an acknowledgment, sends it, and confirms that the acknowledgement has been received. The first general knows this, so she sends an acknowledgement that the second general's confirmation has been received, but must wait for that notice to be confirmed, and so on. Of course, in the real world, the generals can reach various levels of practical confidence, ${ }^{57}$ but they cannot reach absolute certainty. Thus, unless they want to rule out all possibility of a coordinated attack, they must take at least some risk that they might not attack together.

In most business settings, identifying a point past which contracting parties will have sufficient confidence probably has little to do with identifying a particular "acceptance" or the offer that preceded it. The exception to this muddle is the classic case of contracts concluded at a distance with significant delays, usually through the mail — where the communication is punctuated and can, in its entirety, be reconstructed. The "mailbox rule," or any number of similar plausible candidates for an alternate rule, serves a useful coordinating function in those environments. But those cases are of sharply diminished importance in the modern commercial world. As I discuss further in Part III infra, artificially constructing a single definite "acceptance" out of a verbal

53. Adams v. Lindsell, (1818) 106 Eng. Rep. 250 (K.B.).

54. See E.A. Akkoyunlu et al., Some Constraints and Tradeoffs in the Design of Network Communications, in SOSP '75, PROCEEDINGS OF THE FIFTH ACM SYMPOSIUM ON OPERATING SYSTEMS PRINCIPLES 67, 70 (J.C. Browne \& Juan Rodriguez-Rosell eds., 1975) ("In an arbitrary distributed facility, it is impossible to provide complete status.").

55. See Jim Gray, Notes on Data Base Operating Systems, in LeCtURE NOTES IN COMPUTER SCIENCE: OPERATING SYSTEMS 393, 465-66 (R. Bayer et al. eds., 1978).

56. See id.; see also ECONOMICS AND INFORMATION 57 (Pascal Petit ed., 2001); Eric Pacuit \& Rohit Parikh, Reasoning About Communication Graphs, in INTERACTIVE LOGIC 135, 148 (Johan van Benthem et al. eds., 2007).

57. See generally Pacuit \& Parikh, supra note 56. 
conversation requires, at best, the construction of a useless fiction; at worst, it leads to problematic results.

Similarly, parties don't just engage each other informally, without knowledge of contract law; they also often talk in ways that misuse the terminology of contract law and probably cannot be formally mapped onto its substance. For example, in refinancing a mortgage recently, my lender wrote to me of its "counter offer letter, which you've already accepted." ${ }^{58}$ It probably did this just because it wanted its file to match what we had already substantively agreed to elsewhere. As a related matter, it is also common to see agreements that describe themselves as occurring "in one or more counterparts, each of which are originals and all of which constitute a binding agreement." Analyzing such documents from the perspective of the reductive offer-andacceptance model would serve no purpose. In these situations, as in the others I have discussed, analyzing whether at least one of the parties reasonably thinks there is a binding contract would better track the parties' goals, as well as the moral and policy objectives that the law seeks to implement by legally enforcing the parties' promises.

\section{B. Potentially Poor Results}

In addition to needlessly complicating contract formation, the offer-andacceptance doctrine also leads to potentially poor results as the paradigm is stretched. The concern is that applying the paradigm leads to decisions illconsidered on substantive grounds. The offer-and-acceptance model threatens to do more harm than good if we use it to decide difficult cases. ${ }^{59}$

An interesting test case involves definite and concurring offers that cross each other in the mail (or any similar mechanism for delayed communication). For example, suppose I write you (presumably after some preliminary discussions) an e-mail offering to sell you my car for $\$ 12,000$ and you, at roughly the same time, write me an e-mail offering to buy it for the same price. We both then read the crossed e-mails. In such a case, there is no traditional sequence of "offer and acceptance"; the question is whether courts should enforce a contract between the parties. Though this case has very rarely been litigated, ${ }^{60}$ most commentators tend to assume that there should be no

58. E-mail from Tami Rice, Pentagon Fed. Credit Union, to Shawn Bayern (Nov. 23, 2011) (on file with author).

59. As an analogy, consider Stephen Sugarman's similar type of arguments against the "assumption of risk" doctrine in tort law. See Stephen D. Sugarman, Assumption of Risk, 31 VAL. U. L. REV. 833, 835 (1997) ("My argument here is something of a mixed positive and normative one. On the one hand, I offer what I believe to be a parsimonious explanation for most of the existing cases, one that rejects 'assumption of risk' as both superfluous and unilluminating of the real reason for the result. On the other hand, by offering a better way of thinking about the cases, my analysis helps correct the mistakes that I believe some courts have made.").

60. See ReSTATEMENT (SECOND) OF CONTRACTS $\$ 23 \mathrm{cmt}$. d (1981) ("Cases have occurred in which identical offers have crossed in the mails. Such an event is unusual ...."). 
enforceable contract - although they rarely justify that position on substantive grounds. The formal grounds are somewhat clear: in addition to potential problems with consideration (one offer is not given in exchange for another), there has been no classical sequence of offer followed by acceptance. As usual, this formal analysis has obscured the underlying substantive questions.

It is worth a small detour to examine the origins of the classical, formal analysis of this question. That analysis is particularly thin in this area, both doctrinally and substantively; that is, there is almost no case law on the matter. The relevant case law that does exist is nonetheless commonly taken as authoritative even though little attempt has been made to justify the rule on social or business-related grounds.

The doctrine that "cross-offers" are necessarily unenforceable dates to (and largely rests on) a single English case, Tinn v. Hoffman \& Co. ${ }^{61}$ This case appears to have resolved the matter for England and the Commonwealth in dicta $^{62}$ and it is ordinarily the only doctrinal authority for the few American sources that consider the question. ${ }^{63}$ The only reason that the judges in Tinn seem to provide in holding that no contract is formed is that there is no clear way to construct "offer and acceptance" from identical offers that cross each other in the mail. If that indeed is what motivated their thinking (and little else is apparent), the case serves as an excellent example of the potential problems in applying the offer-and-acceptance doctrine mechanically.

The precise reason for the rarity is unclear. Perhaps substantially identical offers rarely cross each other in the first place, but such a phenomenon doesn't seem obviously more obscure than similar problems that have arisen frequently (like revocations that cross acceptances in the mail). Charles Fried, one of the few American writers to address the problem squarely, calls it "largely theoretical" because parties facing the problem "would immediately pick up the telephone to straighten out the confusion.” ChARles FrIED, CONTRACT AS PROMISE 54 (1981). But Fried's supposition seems unconvincing. On one hand, it would prove too much because it would apply to most other problems of transacting at a distance, some of which have persisted alongside telephones. On the other, it is not correct to assume that in all circumstances of crossed offers, parties necessarily think there is something to clarify. As a rough example, if I receive a message from an associate dean saying 'I'm adjusting the fall schedule; would you mind moving your class to 3:00?" at roughly the same time as I've written an e-mail that reads "Actually, I've noticed a conflict; could you move my class to 3:00 instead of 2:00?" then the dean would likely reasonably think she could simply adjust the schedule without further confirmation. To put it differently, I would probably be unreasonable to object later that the class was moved without any agreement to move it. Consider, also, the sorts of cases I discuss at infra text accompanying note 69.

Moreover, even if Fried is correct as a matter of fact, his remark potentially puts the cart before the horse if the question is what the best rule of contract law would be: parties surely wouldn't think they needed to follow up with one another if contract law made enforcement in such cases clear. $C f$. infra note 70 and accompanying text. Even more fundamentally, even if Fried's assumption about the parties is correct, it suggests a substantive rather than formal analysis of the case; I have no objection to courts' refusing to enforce crossed offers if the parties do not expect them to do so.

61. [1873] 29 L.T. 271 (Ex. Ch.).

62. See Mindy ChEn-Wishart, CONTRACt LaW $\S 2.3 .2$, at 65 (4th ed. 2012) (citing Tinn but giving no new substantive justification).

63. See, e.g., E. AlLAN FARNSWORTH, CONTRACTS $§ 2.10$, at 107 (4th ed. 2004). 
In Tinn, one judge in the majority wrote simply that "you cannot make [a contract] by cross offers, and say that the contract was made by one party accepting the offer which was made to him." "64 Judge Blackburn added, "I do not think exchanging offers would, upon principle, be at all the same thing" as an offer followed by an acceptance, but he never suggested what the "principle" was or whether it would be desirable on any substantive grounds. ${ }^{65}$

His one attempt at a functional justification was to hint that it would cause "grave inconvenience" to change the rules despite observing just a few sentences earlier in his opinion: "There is, I believe, a total absence of authority on the point. I do not think, though I am not sure, that the question has ever been raised before." 66

Notably, one judge in Tinn disagreed with the others. Judge Honyman wrote:

I cannot see why the fact of the letters crossing each other should prevent their making a good contract. If I say I am willing to buy a man's house on certain terms, and he at the same moment says that he is willing to sell it, and these two letters are posted so that they are irrevocable with respect to the writers, why should not that constitute a good contract? ${ }^{67}$

The best way to answer the question raised in crossed-offer cases is simply, in my view, to apply the same general principle that I have already outlined: Does one of the parties reasonably think there is a contract, or do both of the parties subjectively think there is a contract? The Restatement Second is not far from this position, at least in its comments. In explaining why crossed offers should not form a contract, it claims that "the ordinary offer does not manifest assent to the formation of a contract in this way." If the Restatement means by this that parties do not ordinarily intend to be bound if their offers cross, that is at least a potentially valuable (and perhaps decisive) substantive reason that courts should not determine that an enforceable contract results from crossed offers.

To put it differently, the question should not be whether an acceptance followed an offer or whether an offer induced an acceptance. In order to achieve the substantive goals of contract law, the question of contract formation should simply be an interpretive one ${ }^{68}$ grounded in the parties' intent and expectations.

64. Tinn, 29 L.T. at 278. (Brett, J.).

65. Id.

66. Id. at 279 (Blackburn, J.).

67. Id. at 275 (Honyman, J.).

68. $C f$. Restatement (SECOND) OF CONTRACTS $\S 23 \mathrm{cmt}$. d ("This is a matter of interpretation; theoretically, just as the offeror may assent in advance to an acceptance, so each of two offerors could assent in advance to a cross-offer."). 
Suppose two people agree simultaneously to a contract in person. They might do this with, for example, quickly exchanged words. In environments where it makes sense, like among contracting parties who know each other well or who share the norms of a quick and hectic marketplace or a professional auction, they might do it with mere glances or hand gestures. Particularly if they then simultaneously shake hands or perform some other joint act, there should be little doubt that the parties have formed an enforceable contract. In the general case, it is unclear why the substantively unimportant lack of literal simultaneity in the crossed-offer cases, where the parties use methods of delayed communication, ought to change that result. The lack of simultaneity does not inherently cause the parties to behave differently, or to have different expectations, from those in cases of in-person simultaneity.

More directly, as a general matter, there are substantive advantages to accelerating the formation of contracts in ambiguous cases where it is nonetheless clear that the parties agree on relevant terms. Most importantly, if the parties agree or are likely to agree, accelerating formation generally promotes potentially beneficial reliance by one or both of the parties. For example, someone planning to sell a car can be more confident in taking steps to execute the sale, or a factory manufacturing an item can begin production earlier. A rule that makes enforcement clear in crossed-offer cases would also probably cut down on the costs of contracting for the parties; it would eliminate the need for the parties to follow up with further e-mails or more direct communication. Similarly, it could discourage the parties from continuing to bargain over terms when further bargaining would likely do nothing other than reallocate the existing contractual surplus (that is, the gains from the contract).

Moreover, in at least some cases of crossed offers, there may be additional moral reasons for enforcement. If the offers are framed explicitly as conditional promises, it is probably wrongful for a party to insist that no contract is formed. Suppose parties exchange e-mails that say, "If you're willing, I promise to enter the joint venture that we discussed." Framed as a moral commitment, such communications probably carry moral obligations, and social morality is one significant pillar of contract law. ${ }^{69}$

69. For a recent discussion of the interplay of morality and efficiency in contract law, see Melvin A. Eisenberg, Actual and Virtual Specific Performance, the Theory of Efficient Breach, and the Indifference Principle in Contract Law, 93 CALIF. L. REV. 975, 1012 (2005) ("'[T] he efficiency of the contracting system rests on a tripod whose legs are legal remedies, reputational effects, and the internalization of social norms, in particular the moral norm of promise-keeping.").

Melvin Eisenberg has defined social morality as follows:

By social morality, I mean moral standards that claim to be rooted in aspirations that apply to all members of the community and, on the basis of an appropriate methodology, can fairly be said to have substantial support in the community or can be derived from norms that have such support. In contrast, critical morality consists of moral standards whose truth does not depend on community beliefs and attitudes, except insofar as such beliefs and attitudes are relevant to the application of the moral standards.

Melvin A. Eisenberg, Disclosure in Contract Law, 91 CALIF. L. REV. 1645, 1651 n.5 (2003). 
It is worth noting that my contention is not that all cross-offers should create enforceable contracts; the touchstone should simply be (as usual in modern contract law) the parties' expectations, and divining such expectations is fundamentally an interpretive question not easily reduced to formulas. An interesting difficulty arises here, one that has been insufficiently explored in contract literature in general: What is to be done when suboptimal law has influenced parties' expectations in a counterproductive way? That is, what if parties expect that cross-offers don't form enforceable contracts merely because the doctrine (thin as it is) has suggested that they don't? There is unlikely to be a comprehensive, general answer to that question; the best response will depend on the strength of the underlying expectations, the benefits to be gained by changing them, and the likelihood that the law could change people's expectations in the first place. ${ }^{70}$

The few commentators to suggest a less richly substantive or interpretive analysis of the problem rarely give reasons for such a view. As in Tinn, the typical reason is often purely formalistic. The Restatement Second suggests an analysis similar to mine, with perhaps a thumb on the scale, as an interpretive matter, against enforceability. ${ }^{71}$ Interestingly, the civil-law tradition appears to reach a similar result for similar reasons to those I have proposed; at least, a Louisiana court, applying civil law, has noted that cross-offers form a contract under the civil law "because (1) there is a concurrence of wills and (2) the law favors the formation of contracts." ${ }^{, 72}$ Similarly, Arthur Corbin reached the right

70. Mark Gergen has helpfully suggested in conversation that an additional reason not to enforce cross-offers is that they do not exhibit the sort of mutual understanding that contracts ordinarily exhibit, where each party knows that the other intended to form a contract. For example, Thomas Scanlon outlines a principle under which contracts should be enforced when, among other things, "A acts with the aim of providing ... assurance, and has good reason to believe that he or she has done so," "B knows that A has the beliefs and intentions just described," "A intends for B to know this, and knows that B does know it," and "B knows that A has this knowledge and intent." Thomas M. Scanlon, Promises and Practices, 19 PHIL. \& PUB. AfF. 199, 208 (1990). Cross-offers arguably lack this distinctive type of agreement. They may, however, still meet Scanlon's principle, at least as much as ordinary cases concluded over delayed communication do, for in many such cases parties may not literally have simultaneous intentions. More importantly, even if cross-offers lack the sort of agreement that Scanlon describes, I am not confident that is a sufficient basis for refusing to enforce obligations that result from them. They may be exceptional sorts of obligations, and perhaps they do not deserve to be called contracts, but the classification of them for these purposes should not affect the functional discussion in the text.

71. See RESTATEMENT (SECOND) OF CONTRACTS $\S 23 \mathrm{cmt}$. d.

72. Spiers v. Seal, 426 So. 2d 631, 634 (La. Ct. App. 1982). Much European commentary appears consistent with this position. See Joseph M. Perillo, Book Review, 37 FordHAM L. REV. 144, 149 (1968) (reviewing $1 \& 2$ Formation OF CONTRACTS: A STUDY OF THE COMMON CORE OF LEGAL SYSTEMS (Rudolph B. Schlesinger ed., 1968)) (referring to "respectable arguments for [forming contracts based on crossed offers] among German, Swiss and Austrian writers"). As Professor Perillo nicely observes, "If the parties have manifested assent to the same terms and, at least, if this manifestation arises out of on-going negotiations, what need is there to impose the additional requirement that there be an offer and acceptance?" Id. Note that the continuation of ongoing negotiations that Professor Perillo mentions may be one feature of contracting context that a case-bycase analysis would illuminate. 
sort of substantive analysis by rejecting an overly formal dependence on the notion of an acceptance. "There is," he wrote, "no inevitable necessity in our adoption of the machinery of offer and acceptance. The rules of contract, like all other rules of law, are based upon mere matters of policy, or belief as to policy."73

Charles Fried has defended the classical view of crossed offers on both formalistic and administrative grounds. He posits two letters sent on Monday that cross one another in the mail and arrive on Wednesday for both parties. Noting that "it seems most natural to me to say that there is no contract," concludes that "what was not an acceptance nor intended as one on Monday cannot turn into an acceptance on Wednesday." conclusion, and it is hard to see why it should be persuasive. But Fried continues to suggest an essentially administrative problem with enforcement of contracts created by crossed offers: "Consider the inconveniences of a rule holding that a contract concluded on Wednesday. Neither A nor B knows that the other is in receipt of his letter, so the circumstances that would create the contract are not known to either party." ${ }^{, 76}$ Fried later undercuts this argument, however, by admitting that the parties both "showed themselves willing to take the risk of being contractually bound without knowing it" merely by sending an offer that could have been accepted. ${ }^{77}$ Ultimately, he rests his position on an assertion of intuition, much like the most generous interpretation of Judge Blackburn in Tinn: finding an enforceable contract "would at least require the promulgation of a rule to that effect, for the result lacks the intuitive naturalness of the standard offer-and-acceptance case." however, is problematic for at least two reasons. First, it amounts to little more than traditionalism in form - to a general assertion, ironically contrary to the tradition of the common law, that judges cannot or should not change the law. Second, it assumes that business parties are familiar with the details of the offer-and-acceptance paradigm; this is probably not true in general, and it is particularly doubtful when there is apparently little more than one case in favor of the proposition in all of Anglo-American contract law's history-an English case dating to the late $1800 \mathrm{~s}^{79}$

73. Arthur L. Corbin, Offer and Acceptance, and Some of the Resulting Legal Relations, 26 YALE L.J. 169, 183 (1917); see also K. N. Llewellyn, On Our Case-Law of Contract: Offer and Acceptance, I, 48 YALE L.J. 1 (1938); K. N. Llewellyn, Our Case-Law of Contract: Offer and Acceptance, II, 48 YALE L.J. 779 (1939).

74. FRIED, supra note 60, at 53.

75. Id.

76. Id.

77. Id. at 54 .

78. Id.

79. An old contract-law treatise, William Herbert PAGE, THE LAW OF CONTRACTS § 151, at 224 (2d ed. 1920), cites what appears to be a second case on the matter, an obscure unpublished opinion from Kentucky that touches only briefly on the question without providing any substantive reasoning. Oddly, the treatise appears to cite the case incorrectly; the unpublished case can be found at 
III.

\section{MOVING BEYOND OFFER AND ACCEPTANCE}

This Part makes two related arguments. The first is somewhat more radical than the discussion of Part II; it is that in focusing excessively on a moment of contract formation, the offer-and-acceptance doctrine wrongly suggests that we can determine whether contracts exist solely from a putative acceptance and information that precedes it. Instead, my argument is that information subsequent to classical acceptances can and should influence contract formation. Related, but much more radical, my second argument is that contract formation should simply not be seen as necessarily irreversible in most cases; instead, contract law should, for reasons of morality and efficiency, adopt a new theory more consciously tied to the purposes of expectation damages in the first place. On this view, it is not words or agreements that alone cause a contract to be formed. Rather, those words and those agreements interact with the parties' ongoing circumstances, and the precise moment of appropriate contract formation may ultimately have nothing to do with the agreements the parties exchanged but rather with other circumstances that arise later in their dealings. Perhaps ironically, such a theory could also offer the parties better certainty as to the precise timing of contract formation than the current offer-and-acceptance model.

\section{A. Conversation Plus: Putting Dialogue in Its Place}

Historically, the doctrine of offer and acceptance led to odd and unjustifiable results when applied with the superficial analytical rigor of classical contract law. For example, under classical contract law, an offer of a unilateral contract ("I'll pay you $\$ 100$ if you paint my house") could not be accepted by partial performance of the invited act (painting most of the house) even though the painter would clearly believe himself to have a right to be paid by the offeror. ${ }^{80}$

That doctrinal error has been corrected, ${ }^{81}$ but a potentially significant remaining problem is that the offer-and-acceptance doctrine tries to maintain that communication leading up to a putative offer or acceptance is sufficient (coupled with the candidate offer or acceptance in question) to determine its legal status. Consider the following hypothetical dialogue between an artist at an art festival and a potential buyer:

1. B: "I'd like to buy your painting for $\$ 500$."

Ratterman v. Campbell, 26 Ky. L. Rptr. 173 (1904). For its part, the Page treatise states simply "crossoffers do not constitute a contract" without attempting a justification. PAGE, supra, at 224. There is arguably contrary American authority as well. See, e.g., Morris Asinof \& Sons, Inc. v. Freudenthal, 186 N.Y.S. 383 (N.Y. App. Div. 1921) (referenced in Perillo, supra note 72).

80. See Peter Meijes Tiersma, Reassessing Unilateral Contracts: The Role of Offer, Acceptance and Promise, 26 U.C. DAVIS L. REV. 1 (1992).

81. RESTATEMENT (SECOND) OF CONTRACTS $§ 45$ (1981). 


\section{2. $S$ : "Agreed."}

3. B: "Do you take credit cards?"

4. $S$ : "No."

5. B: "Oh, sorry, then I have no way to pay."

A classical contract theorist-and, too often, those who write Contracts exams - may conclude that we can determine for certain at step 2 (or, perhaps more precisely, immediately upon the completion of step 2) in the dialogue that there is a contract. Maybe he or she would pick some other stage of the dialogue. Regardless of the particular step such a theorist would decide sets forever the parties' legal obligations to each other, my concern is that the question is the wrong one to be asking. It is only after considering what is later said that we can know whether the parties intended after step 2 to be bound; it is simply not the case, I think, that we want only the communications and acts up to a certain time to matter in determining the presence of a contract at that time.

Now, perhaps steps 3 through 5 matter only as interpretive clues; that is, perhaps they affect our determination about whether there is a contract after step 2 by giving a factfinder greater information about what statements 1 and 2 meant at the time they were uttered. My contention is that the problem is deeper, however, and that what is said after step 2 can actually cause what would otherwise have been a contract to evaporate. It is not that a right or duty arose upon step 2 and was later removed because of some sort of excuse to performance (in this case, perhaps something like impracticability under the circumstances); it is that statement 2, no matter how unequivocal an acceptance in form, simply does not alone provide a mechanism for a contract to be formed. For example, statement 2 might read "You have a deal; I am very pleased to sell it to you at that price and will begin to pack up the painting immediately." Nonetheless, it would not necessarily create a contract, even if statement 1's status as a classical offer is similarly strengthened, perhaps along the lines of "I propose a contract for the sale of your painting and will purchase it for $\$ 500$ if you agree."

My contention may amount to little more than a simple recognition that it is not an utterance like that in step 2, but rather that utterance combined with something more (even if just a subsequent period of silence) that serves as an acceptance. But that recognition alone suggests that an analysis of contract formation should focus more on a course of conduct as a whole rather than on a specific hypothetical moment of contract formation.

Consider what has become the standard practice for online retail commerce: customers add items to a virtual "shopping cart" or "shopping basket" and then "check out," supplying payment information. ${ }^{82}$ Even then, it's unclear whether a sale has been completed; many organizations provide

82. See generally ZHENG QIN, INTRODUCTION TO E-COMMERCE (2009). 
opportunities to cancel (and have "terms" posted on the site that purport to provide such a cancellation as a matter of right to customers) after the final check-out. Many airlines, for example, provide the opportunity to cancel even "nonrefundable" tickets up to 24 hours after purchase; it is unclear whether most consumers know of this or not, but I suspect they don't. ${ }^{83}$ Sometimes, buttons on a website are labeled "confirm" but do not themselves trigger what is legally an acceptance; that is, often even terminology that suggests finality does not in practice lead to finality. General expectations of customers seem to be something like the following: they continue interacting with a website until it gives a final confirmation, with indicia of confirmation that have become familiar (an order number, an e-mail confirmation). Even then, there may well be legitimate and appropriately enforceable expectations that one side, or both, can cancel the order upon subsequent contact in a reasonable amount of time (say, a few minutes, and in many situations perhaps longer). Perhaps in many cases consumers expect to be able to refuse to accept a shipment of goods from a website, and thus to avoid payment.

Overall, there is a spectrum rather than a binary, on-off mechanism: at some point, the transaction runs its course, and both sides' attention returns to other things. It is only at that point, often, that we can evaluate whether a contract has been made. That evaluation has little to do with one particular offer and one particular acceptance.

\section{B. Acceptance and Irreversibility: Tying Contract Formation to the Purposes of Contract Remedies}

The discussion so far points the way toward what may be a furtherreaching reconsideration of contract doctrine - specifically, a questioning of the assumption that contracts are generally irreversible and that expectation damages are fully available a moment after the formation of a contract. Other than tradition and administrative simplicity, it is unclear what justifies this rule - and even those two bases seem relatively weak here. The "tradition" is just a tradition among lawyers and has no necessary direct bearing on the way that contracting parties conduct themselves. Most contracting parties probably don't rely on it, particularly (as we shall see shortly) in cases where so little time has passed since the putative formation of a contract that reliance is not even possible. The "administrative simplicity" is itself murky, for it leads courts to decide potentially unnecessary questions about the precise moment of contract formation.

83. The Department of Transportation has relatively recently adopted regulations that require a 24-hour refund period for ticket sales in many circumstances. See 14 C.F.R. $§ 259.5$ (2011) (requiring that airlines publish a policy "allowing reservations to be held at the quoted fare without payment, or cancelled without penalty, for at least twenty-four hours after the reservation is made if the reservation is made one week or more prior to a flight's departure"). 
Consider a case where a contract is formed and shortly thereafter, without any reliance on either side, one of the parties decides the contract was a bad idea and wishes to cancel its formation. Prior commentary has recognized at least two ways of treating this scenario: (1) the typical rule of contract law, enforcing the contract with expectation damages; $;{ }^{84}$ (2) a greater emphasis on reliance damages in contract law in general, and perhaps a limitation of contract enforcement to that level of damages in these cases (implying no damages here because there is no reliance). ${ }^{85}$

There is an intermediate course, however. Expectation damages offer significant advantages in upholding morality and in encouraging efficient performance of, and reliance on, contracts. ${ }^{86}$ But as I will explain, the benefits of an expectation-damages regime are unclear where (1) no reliance has yet been possible, (2) no performance has yet been possible, and (3) no opportunity for speculation exists that would make rescission unfair. Accordingly, there seems to be little justification for offering expectation damages in cases where one party decides shortly after formation, based on an internal reevaluation, that the contract is a bad idea. Such a reevaluation would not normally provide the basis for any sort of excuse related to "mistake" or "unexpected circumstances"; my contention is that rescission should nonetheless be available.

\section{Insufficient Justifications for Enforcement: Immediate Irreversibility and the Functions of Contract Enforcement}

To see why this view of contract formation is both moral and efficient, it will be helpful to review the reasons for contract enforcement (through expectation damages) in general. As Melvin Eisenberg and I have previously explained, ${ }^{87}$ expectation damages broadly serve two instrumental goals: they encourage efficient rates of performance (along with precaution to prevent unintentional breach) by promisors, and they encourage efficient reliance by promisees. As an example of these two benefits, consider a contract for the manufacture of a custom-built piano for $\$ 8,500$. Idealized expectation damages that incorporate the piano's entire subjective value to the promisee (the buyer) are necessary for the promisor (the manufacturer) to incorporate into its own cost-benefit calculus the harm it would cause by failing to deliver the piano as

84. This is, of course, the general doctrinal result. See, e.g., Melvin A. EIsEnBERG, FOUNDATIONAL PRINCIPLES OF CONTRACT LAW (forthcoming 2014) (manuscript at 540) (on file with author) ("The instant an offer is accepted, each party becomes liable for expectation damages if he fails to perform, even if he changes his mind only a nanosecond after the contract is formed.").

85. See L. L. Fuller \& William R. Purdue, Jr., The Reliance Interest in Contract Damages: 1, 46 Yale L.J. 52, 52 (1936); see also Grant Gilmore, The DeAth of Contract (Ronald K.L. Collins ed., 2d ed. 1995).

86. For a detailed exposition of this point, refuting many recent objections to the efficiency of expectation damages, see generally Bayern \& Eisenberg, supra note 10.

87. Id. at $2-8$. 
promised. ${ }^{88}$ In doing so, expectation damages encourage efficient performance. They also, in a closely related way, cause the promisor to take precaution against accidental breach - such as the piano falling apart a few days after it is delivered, which would amount to a breach of warranty.

Expectation damages also encourage efficient reliance on the promisee's end. Once the contract is made, the promisee can, for example, begin to take piano lessons knowing that they will pay off in the enjoyment of playing the purchased piano. ${ }^{89}$

Finally, expectation damages uphold social morality; they comport with socially moral norms of promise-keeping, and they prevent one party from taking advantage of another:

We cannot know whether $A$ would have rendered ... performance to $B$ for any lesser price. Requiring $A$ to accept any lesser price would therefore unfairly convert $A$ from a voluntary to an involuntary actor, because if $A$ had known in advance that the contract price was not enforceable in full, he might not have agreed and performed. ${ }^{90}$

Expectation damages essentially bolster a bet that the parties have made, and it would be unfair to let one of them undo that bet subsequently: "[I]n most cases allowing a promisor to measure damages by anything less than the contract price would have the same unfair quality as allowing a person who has lost a fair bet to renege." 91 Of course, this analysis is not meant to suggest that it is morally necessary to enforce promises even when unconscionable, or even when excused by impossibility or some other factor. The point is just that in the general case, it is unfair to let a party make a contract and then break it with impunity without any supervening moral or instrumental justification.

Perhaps surprisingly, these generally accepted reasons in favor of expectation damages very poorly justify the notion that a contract must be irreversible immediately after acceptance. Recall that expectation damages (1) promote efficiency by encouraging efficient performance (and precaution against unintentional nonperformance), (2) also promote efficiency by enabling efficient reliance, and (3) are ordinarily consistent with social morality because they prevent parties from (a) converting others from voluntary into involuntary actors and (b) reneging on fair bets. None of these reasons supports immediate irreversibility of contracts.

88. Though the measurement of damages is beyond the scope of this paper, it is worth pointing out that expectation damages might not, in the real world, achieve this idealized objective; indeed, depending on how customized the order in the example is, specific performance rather than expectation damages may be a more suitable remedy. See Eisenberg, Actual and Virtual Specific Performance, supra note 69, at 999-1003.

89. Cf. Bayern \& Eisenberg, supra note 10, at 6-8 (discussing beneficial reliance on contracts).

90. Id. at 5 .

91. EISENBERG, supra note 84 (manuscript at 980). 
To remain with the example of a custom-ordered piano, suppose the customer commits to a sale (by signing a document or whatever else is required under the Statute of Frauds ${ }^{92}$ and all other doctrinal requirements). Suppose immediately afterwards, he changes his mind — or he receives a call from his partner, who remarks how bad an idea it would be to buy a custom-ordered piano for $\$ 8,500$. A failure to enforce the "contract" that current doctrine assumes has been made would not undermine any of the goals of expectation damages: the manufacturer has not had a chance to perform or to take precautions against unintentional breach, the buyer has not had a chance to rely, and probably no fair bet has been broken.

The first two of these observations (the instrumental ones) should be obvious because they are almost matters of definition in the example. The third-concerning whether a fair bet has been broken-requires more discussion. Perhaps on some level the buyer has broken a bet he's made with the seller - specifically, a bet that he wouldn't change his mind after agreeing to the purchase. The seller could, at least theoretically, have offered a price of $\$ 8,500$ (rather than some higher price) to cause the buyer to make an impulsive purchase; the seller thus perhaps risked some lost component of the contractual surplus in exchange for a more likely inducement to an additional marginal sale.

This possibility suggests an appropriate fact dependence in determining whether a purported contract should be treated as irreversible immediately after it is classically "formed." On one side of the spectrum, parties may make a specific financial or psychological bet concerning the certainty of the transaction. To put it differently, they may specifically intend to allocate the risk of reversibility to one of the parties. In the real world, pure financial instruments - futures and options contracts, for example - often carry this explicit assignment of risk. Note that an attempt to repudiate a futures contract an instant after it is formed does not necessarily or directly cause a social deadweight loss, frustrate reliance, or inhibit effective planning. Its primary problem is that it is unfair given the assignment of risks to which the parties have agreed. That is, it would allow one party to speculate at the expense of the other in ways that the parties almost certainly intended (or would have intended) to prohibit.

Perhaps surprisingly, then, the reason a financial transaction like a stock sale should be irreversible appears, in the first instance, to be moral. Any negative instrumental effects proceed, as they often do in contract law, ${ }^{93}$ from this transactional unfairness in a secondary way: if traders cannot expect stock

92. For example Uniform Commercial Code would ordinarily require that a contract to purchase an $\$ 8,500$ piano be memorialized in writing. U.C.C. $\$ 2-201$ (2012).

93. Cf. Eisenberg, Actual and Virtual Specific Performance, supra note 69, at 1012 (explaining how the theory of efficient breach generates inefficiency by undermining the contracting system and the moral bases on which it partially depends). 
sales or futures contracts to be reliable, they will be less inclined to enter into them, and as a result a market that is at least provisionally valuable weakens.

On the other side of the spectrum, an ordinary sale of goods in a store likely does not carry, or need to carry, such a definite assignment of riskwhich is presumably why it is normal for consumers to expect they can return an unopened, unused good unless told explicitly that "all sales are final." 94 It is possible that in the case of a custom-negotiated sale, the seller indeed has asked the buyer to accept a risk that the buyer might change his mind (and the buyer has accepted that risk), but it would be groundless to assume, without more, that that is the ordinary case.

Accordingly, to be precise, my argument is not that all contracts must be conditionally reversible; it is that contracts should be provisionally reversible unless the parties have explicitly or tacitly agreed otherwise.

Putting aside direct, intended shifts of risk, the functional reasons for expectation damages directly suggest the conditions that should make contracts irreversible (and the timing of such irreversibility). Once the parties can make decisions that influence the likelihood of performance, the threat of enforcement is necessary, and that alone is probably sufficient for contracts to be treated as irreversible. The same is true of the possibility of decisions made in reliance on the contract. Once they materialize, the possibilities of performance and reliance provide sufficient instrumental reasons for treating contracts as irreversible. To put it differently, the instrumental reasons are probably sufficient once they arise, particularly because it is not unfair, after all, to ask parties to do what they promised to do.

There is an additional moral boundary condition, separate from the instrumental concerns, that ought to trigger irreversible contract formation. Parties should not be permitted to rescind a contract if it would give them an opportunity to speculate at the other party's expense. This opportunity for speculation ordinarily arises in two ways. First, there is a rapidly changing market, such as the public stock markets. In such cases, sales ought to be final; the opportunity to speculate based on small price differences should be presumed. Second, a party might learn new material information (ordinarily from some source external to the contracting parties themselves) that would affect the value of the contract. For example, in the case of the sale of a custom-made piano, suppose the promisee learns shortly after the sale (but before reliance or performance are meaningfully possible) that the price of some component necessary to the manufacture has skyrocketed as the result of a shortage. Given the normal terms on which people negotiate, it is unfair to shift that risk after concluding the negotiation. Once the new information is

94. Indeed, it seems likely that given prevailing retail policies at outlets like Target, many customers expect they can even return undamaged goods once opened, even after a relatively long interval (like ninety days). See Return Policy, TARGET, http://help.target.com/help/subcategoryarticle ?childcat=Return+policy (last visited Oct. 20, 2014). 
learned, it becomes morally problematic to let a party reverse the contract merely because it is no longer desirable to that party. And though expectation damages would not serve their ordinary instrumental functions of directly promoting efficient reliance or performance in such cases, enforcement is not instrumentally problematic. It does not cause a social loss; it simply allocates a different amount of the contractual surplus to the buyer (or the seller) than he or she might have hoped.

Accordingly, contracts should be treated as finally formed either when (1) the instrumental concerns discussed above (the materialization of a performance or reliance possibility) trigger, or (2) rescission would permit one party to obtain an advantage through speculation.

Speculation, for these purposes, should be interpreted relatively narrowly. Merely changing one's mind does not, on its own, permit non-negotiated speculation. Relatedly, as I mentioned above, the acquisition of new information that affects the value of the contract should ordinarily matter only when it comes from the external world, not the parties themselves. If a party "learns" new information through introspection and desires to change her mind accordingly, it is hard to say that permitting her to change her mind is unfair unless, as I have already discussed, (1) the parties have explicitly assigned the risk of that "evaluative" mistake to one of the parties; $;{ }^{95}$ or (2) there is some instrumental reason to do so, such as the reasons behind promoting efficient performance and reliance. Likewise, if a party learns new information after classical contract formation from the other party, that reflects merely a manipulative failure by the other party to disclose relevant information. For example, it is difficult on moral grounds alone for a car dealer to insist on the performance of an agreement to purchase a new car if, right after the purchase, he says to the buyer, "Ha! I'm glad you've made this purchase. I didn't think you would, because the car is a real clunker, and it's been through three floods and a bedbug infestation. I'm surprised you didn't ask about those things. Too late now."

In other words, though it is always possible for parties to choose to assign special risks in a contract, if the parties have not done so and no other instrumental reason has yet arisen to support contractual obligations, it is difficult to see why it is a plausible moral argument that what amounts to moral fraud should be permitted merely because a victim has already provisionally fallen for it. Even in cases where parties are permitted to deal sharply with one

95. For more on "evaluative" versus other sorts of mistakes, see generally Melvin A. Eisenberg, Mistake in Contract Law, 91 CALIF. L. REV. 1573, 1577 (2003) (describing "evaluative mistakes" as arising "when an actor who was capable and well-informed at the time he made a contract comes to believe that his choice to make the contract was mistaken due to a change in either his preferences, his subjective valuation of the performances due under the contract, or the objective or market value of those performances"). 
another for instrumental reasons, ${ }^{96}$ it is hard to see why those instrumental reasons would independently suffice to require enforcement of a contract immediately after classical contract formation if they don't require such enforcement immediately before contract formation. For example, rules allowing nondisclosure of material information in contract law are usually defended in economic terms by those who suggest some type of productive incentive for discovering new information about the world. ${ }^{97}$ But such instrumental concerns are not sufficient to lead to obligations without ordinary contract formation; it is difficult to see why they should do so if the other instrumental and moral reasons in favor of contract formation do not support enforcement in a given instance.

A final reason that might be seen to support the classical notion of irreversible contract formation upon acceptance is that parties supposedly have a moral duty to keep their promises immediately once they are made. This proposition, however, seems questionable to me. My own moral intuition is that someone who says, "I promise to take you out to dinner tomorrow. Oh, wait; sorry. I can't," has not actually made a moral commitment. This example suggests that the moral obligations associated with promises, like the legal obligations associated with contracts, don't really start upon an utterance, but upon an utterance plus something more (silence, course of conduct, and so on). ${ }^{98}$ Indeed, often the possibility of performance-related preparations, of reliance, or of new material knowledge - that is, the same factors that ought to matter for contract law-seem necessary to trigger the moral commitment associated with a promise in the first place. A reversal of a promise before such possibilities materialize may seem fickle, but it is not obviously immoral in all or even most cases.

\section{Affirmative Arguments for Reversibility}

So far, my argument has been largely negative: there is no reason, given the usual goals of contract enforcement through expectation damages or similar mechanisms, that contracts should necessarily be seen as irreversible. This is enough at least to lead us to seriously question an otherwise largely unquestioned feature of classical contract law. But there are also specific, affirmative reasons to move away from the classical rule. In particular, there are several reasons to believe a more flexible set of rules concerning formation would promote greater efficiency than a more temporally static view.

96. See Eisenberg, Disclosure in Contract Law, supra note 69, at 1647 ("[S]ocial morality indicates that when one party knows a material fact that is relevant to a proposed contractual transaction, and knows that the other party does not know the fact, nondisclosure normally is sharp dealing, or a kind of moral fraud. But against all this, in some classes of cases a requirement of disclosure can lead to inefficiency by decreasing the incentive to invest in the discovery of productive information.")

97. See id. at $1664-75$.

98. Cf. infra Part III.A (discussing the role of temporal context in dialogue). 
Most fundamentally, the economic gains of contract law arise ultimately from enforcing the parties' real agreement. ${ }^{99}$ To hold someone to enforceable obligations immediately upon saying "I accept" would likely be to get the parties' intentions wrong, at least in many cases. Specifically, it likely runs against the grain of commonly accepted prospect theory in behavioral economics - the familiar notion that losses are psychologically weightier than gains. ${ }^{100}$ Though the psychological findings of prospect theory are often misunderstood by legal economists and depend on the framing of transactions $^{101}$ (and thus would require greater empirical support for us to draw specific conclusions from them), it is plausible that when parties wish to reverse a contract a few minutes after forming it, they will perceive their inability to do so as a loss, whereas the other party will perceive her lost expectations merely as a forgone gain.

In any case, the more general point is that where commercial norms may permit some fluidity, it is counterproductive to insist on a lack of fluidity in setting the moment of contract formation.

The danger of that lack of fluidity, if parties become aware of it, leads to a secondary instrumental problem, which is that it will tend to discourage contracting and to increase the costs of contract negotiation and drafting. Parties will be more hesitant to enter agreements if they perceive the agreements as creating duties sharper than those they expected. They might insist on explicit disclaimers, spend more time reading refund policies carefully, and so forth. All that is a definite loss; it applies even to cases where no disagreement ends up arising.

Moreover, the administrative benefits of a regime of irreversible contract formation are illusory. As is quite common in legal rhetoric, ${ }^{102}$ "certainty" is often an argumentative placeholder without substance. A rule that parties can opt out of contracts a few minutes after formation in the absence of performance, reliance, or speculation would not be especially difficult for courts to administer. In the case of written contracts, for example, it would be easy to produce a written request for rescission made a few minutes after classical formation, or to physically strike a signature from the original document. Indeed, in view of the discussion of Part II, the classical doctrine of offer and acceptance seems to create needless administrative headaches, and

99. See Shawn J. Bayern, Rational Ignorance, Rational Closed-Mindedness, and Modern Economic Formalism in Contract Law, 97 CALIF. L. REV. 943, 960 n.53 (2009).

100. Daniel Kahneman \& Amos Tversky, Prospect Theory: An Analysis of Decision Under Risk, 47 ECONOMETRICA 263 (1979).

101. Cf. Shawn J. Bayern, Comment, Explaining the American Norm Against Litigation, 93 CALIF. L. REV. 1697, 1711 (2005) ("In general, loss aversion reflects the way in which a party 'frames' a change in utility, so ... alternative explanations ... may be plausible on a theoretical level; empirical testing would be required to decide which account more accurately describes potential plaintiffs.").

102. See generally Bayern, Against Certainty, supra note 50. 
this is not surprising; it requires the determination of a moment of contract formation when the moment is otherwise ordinarily irrelevant on substantive grounds. ${ }^{103}$

Though the view of acceptance as final is rarely questioned, there is one area where contract law has adopted a set of rules at least loosely consistent with what I am proposing. These rules turn out not to be substantively important in many cases any longer, but their existence suggests that the fluidity and substantive responsiveness that I am proposing are not categorically unworkable. In particular, in contracts concluded at a distance (such as through the mail), a problem sometimes arises when an acceptance by action is invited and performed but never communicated to the offeror. So, for example, an offer letter might say "If you loan my brother money, I guarantee that I'll pay you back if he doesn't." "104 There is a tension in contract law here: if the recipient of that letter makes a loan, that itself amounts to acceptance, and a contract is concluded. ${ }^{105}$ However, it is unreasonable to expect the offeror to assume the offer has been accepted if she is not notified of acceptance. The Restatement Second addressed this problem by treating the offeror's duty as "discharged" unless the promisee "exercises reasonable diligence to notify the offeror of acceptance," the offeror in fact learns of acceptance through some other means, or the offer originally indicated that no acceptance would be required. ${ }^{106}$

The Restatement Second's approach seems broadly reasonable, but note that it permits a contract to be accepted but then for its duties to evaporate when there is no reasonable notice of the acceptance. That result ought to be no less strange to a contract formalist than what I have proposed, which is that a classically "formed" contract might nonetheless be "unformed" in situations where a party harmlessly changes her mind.

\section{CONCLUSION}

Most of the formalism of classical contract law has thankfully eroded in favor of a modern contract law responsive to concerns of morality and policy. ${ }^{107}$ One feature of classical law that hasn't eroded, perhaps because it seems even more intuitive than the other axioms that were once accepted by formalist contract-law theorists, is an assumption that contracts require an offer and an acceptance.

103. The relatively functional, anti-formalist Uniform Commercial Code recognizes as much when it specifies that "[a]n agreement sufficient to constitute a contract for sale may be found even though the moment of its making is undetermined." U.C.C. § 2-204(2) (2002).

104. Cf. ReSTATEMENT (SECOND) OF CONTRACTS $\S 54$ cmt. d, illus. 5-6 (1981).

105. Id. $\S 54(1)$.

106. Id. §54(2).

107. See generally Melvin Aron Eisenberg, The Emergence of Dynamic Contract Law, 88 CALIF. L. REV. 1743 (2000) (describing the replacement of static, formal rules with dynamic, substantive rules in contract law over the twentieth century). 
That assumption is factually untrue, and the rules that rest on it are doctrinally confusing and normatively undesirable. Like most of classical contract law, and like analogously poor doctrines in tort such as "assumption of risk," ${ }^{108}$ the classical rule covering offer and acceptance should be swept away in favor of substantive, social concerns.

Most of the changes I have proposed are not radical. For example, there would be few reverberations throughout contract law from eliminating the stylized notion of acceptance that appears in the International Filter case and moving instead toward a more direct substantive inquiry concerning the parties' expectations. ${ }^{109}$ Nor would it shake contract law's foundations to admit that some "cross-offers" should form enforceable contracts. Even more broadly, it is simple prudence - simple application of morality and policy - to recognize that taking the offer-and-acceptance paradigm too seriously threatens at best needless work and at worst undesirable results. Contracts arise in a variety of ways, and it should be no surprise that the modes of formation adopted by the relatively small community that classical contract theorists envisioned are not the exclusive modes through which business and other affairs proceed. Courts should simply ask what parties reasonably think their obligations are, rather than forcing their interactions into what may not be a natural formality. ${ }^{110}$

My further-reaching proposals - that proper contract-formation rules require greater sensitivity to acts subsequent to acceptance, and that enforceability should not depend on "formation" alone but on the possibilities of (1) decisions that affect performance, (2) decisions that affect reliance, and (3) speculation - are admittedly more radical. Still, as I have explained, they cannot by definition frustrate reliance, and they would likely not upset expectations either. Indeed, they would probably track most parties' expectations better than the existing offer-and-acceptance paradigm. Courts could manage these changes incrementally if needed, permitting at first relatively narrow exceptions to classical formation doctrine and eroding the classical notion that legal rights and duties are altered forever "only a nanosecond after the contract is formed." 111

108. Cf. Sugarman, supra note 59.

109. See supra Section II.A.1.

110. For discussion of the notion of "natural formalities," see Lon L. Fuller, Consideration and Form, 41 COLUM. L. REV. 799 (1941).

111. EISENBERG, supra note 84 (manuscript at 540). 
